\title{
PROGRAM KEMITRAAN WILAYAH (PKW) RINTISAN AGROTECHNO-EDUPARK PURWOSARI SEMARANG
}

\author{
Etty Soesilowati ${ }^{1}$, Nana Kariada.TM², Efryani Sumastuti ${ }^{3}$, Avi Budi Setiawan ${ }^{4}$ \\ ${ }^{1}$ Universitas Negeri Semarang \\ ${ }^{2}$ Universitas Negeri Semarang \\ ${ }^{3}$ Universitas PGRI Semarang \\ ${ }^{3}$ Universitas Negeri Semarang
}

ettysoesilowati@mail.unnes.ac.id,nana.kariada@mail.unnes.ac.id, efryanisumastuti@yahoo.co.id, avibs@mail.unnes.ac.id

\begin{abstract}
Abstrak
Bappenas mengagendakan untuk membangun Science Park di 34 provinsi dan Techno Park di 100 kabupaten. Pemerintah Kota Semarang melalui Dinas Pertanian berhasil memanfaatkan lahan eks bengkok menjadi kawasan kebun buah sebagai rintisan Agrotekno-Edupark. Permasalahan: pertama, rendahnya kualitas \& kuatitas sumber daya pertanian. Kedua, terbatasnya anggaran, serta belum optimalnya pemanfaatan sarana dan prasarana kebun Dinas Pertanian; ketiga, belum terintegrasinya program pemerintah daerah serta belum tersedianya instrument pengaturan. PKW merupakan bentuk kolaborasi Dinas Pertanian Kota Semarang, UNNES, UPGRIS, BATAN serta Yayasan Obor Tani. Tujuan PKW rintisan Agrotechno-Edupark Purwosari Semarang adalah untuk : (1) menerapkan teknologi pertanian yang bersifat spesifik lokal, (2) tempat pelatihan, pemagangan, inkubasi bisnis, diseminasi teknologi, dan pusat advokasi bisnis, (3) wahana rekreasi Pendidikan, (4) serta meningkatkan pendapatan petani dan PAD. Kegiatan dilakukan selama 3 tahun menggunakan pendekatan community based learning dan Quadruple Helix. Metode yang digunakan meliputi : sekolah lapang alih teknologi, pelatihan Guiding, pembentukan KUB, pelatihan diversifikasi produk olahan, pendampingan manajemen dan legalitas usaha, serta penyusunan naskah akademik retribusi bidang pertanian. PKW efektif karena meningkatkan produktivitas buah-buahan lokal lebih dari 100\% dan menghasilkan 3 kelompok wirausahawan baru yang saling mendukung, meliputi bisnis buah-buahan, kuliner, dan jasa wisata yang berimbas pada meningkatkan pendapatan petani dan masyarakat sekitar.
\end{abstract}

Kata Kunci : Program Kemitraan Wilayah, Agrotechno-Edupark

\section{PENDAHULUAN}

Pemerintah Indonesia melalui Bappenas mengagendakan untuk membangun Taman Science (Science Park) di 34 provinsi dan Taman Teknologi (Techno Park) di 100 kabupaten yang dituangkan dalam program quick win sebagai upaya peningkatan kapasitas inovasi dan teknologi dalam rangka hilirisasi/komersialisasi hasil-hasil riset domestik [BAPPENAS, 2019]. Taman Sains dan dan Taman Teknologi (TSTP) oleh Kementerian Pertanian (Kementan), dirinci menjadi tiga kelas yaitu :

Pertama, Taman Sains dan Teknologi Pertanian Nasional (TSTPN) atau National Agro Science Techno Park, adalah pusat pengembangan sains dan teknologi pertanian maju serta pusat penumbuhan wirausaha baru di bidang teknologi maju dan Pusat layanan teknologi pertanian maju ke masyarakat. 
Kedua, Taman Sains Pertanian (TSP) atau Agro Sains Park (ASP) yang berada ditingkat Provinsi dan dikembangkan di lokasi Unit Pelaksana Teknis penelitian atau Kebun Percobaan. TSP diarahkan sebagai: (1) Tempat pengembangan invensi bidang pertanian untuk menjadi inovasi yang dilengkapi dengan unit percontohan berskala pengembangan, berwawasan agribisnis hulu-hilir, bersifat holistik dan komprehensif dalam pengembangannya, (2) Tempat kegiatan pengkajian untuk perbaikan teknologi dan perekayasaan kelembagaan pendukung usaha agribisnis untuk mengantisipasi perubahan lingkungan biofisik dan sosial ekonomi, (3) Tempat penciptaan ilmu pengetahuan dan teknologi oleh peneliti dari lembaga litbang pemerintah, dosen perguruan tinggi, dan pakar teknologi, yang siap diterapkan untuk kegiatan serta pengembangan usaha, (4) penyedia solusi solusi teknologi yang tidak terselesaikan di tingkat Kabupaten/Kota, (5) sebagai pusat pengembangan aplikasi teknologi pertanian tingkat lanjut bagi pengembangan perekonomian lokal.

Ketiga, Taman Teknologi Pertanian (TTP) atau Agro techno park (ATP) berada di tingkat kabupaten/kota dan dikembangkan di lahan pemda. TTP adalah: (1) tempat untuk penerapan teknologi pertanian hulu-hilir berwawasan agribisnis yang bersifat spesifik lokasi, (2) tempat untuk percontohan dan penerapan inovasi yang telah dikembangkan di TSP, dan (3) tempat pelatihan, pemagangan, inkubasi kemitraan usaha, diseminasi teknologi, dan pusat advokasi bisnis ke masyarakat luas.

Pemerintah Daerah Kota Semarang telah memprioritaskan pembangunannya pada sector pertanian. Meskipun tidak terlalu besar tetapi sector pertanian menyumbang PDRB Kota Semarang sebesar 0,83\% [BPS, 2012]. Kota Semarang berpenduduk 1.729.428 jiwa, dimana 45.815 orang tercatat bermata pencaharian sebagai petani. Namun demikian, hanya 9.603 orang yang tergabung dalam kelompok tani dan tersebar pada 371 kelompok [Dinas Pertanian Kota Semarang, 2018]

Dalam satu dekade terakhir Pemerintah Kota Semarang melalui Dinas Pertanian berhasil memanfaatkan lahan eks bengkok menjadi kawasan kebun buah. Kawasan kebun buah tersebut tersebar di berbagai wilayah di Kota Semarang, meliputi di Kecamatan Gunungpati, Kecamatan Ngaliyan, Kecamatan Tembalang, Kecamatan Pedurungan, dan Kecamatan Mijen.

Tabel 1. Lokasi Kebun, Luas Lahan dan

Komoditas Kebun Buah dibawah

Pengelolaan Dinas Pertanian Kota Semarang

\begin{tabular}{|c|c|c|}
\hline No & Lokasi Kebun & $\begin{array}{c}\text { Jenis Tanaman(Pohon/ } \\
\text { batang) }\end{array}$ \\
\hline 1. & $\begin{array}{l}\text { Kebun Purwosari } \\
\text { A } \\
\text { Kel. Purwosari. } \\
\text { Kec. Mijen } \\
\text { 2,5 Ha }\end{array}$ & $\begin{array}{l}115 \text { Durian, } 95 \\
\text { Kelengkeng, 100 Jambu } \\
\text { kristal, 40 Sirsat madu, } \\
20 \text { Kelengkeng dan } 7 \\
\text { Jeruk }\end{array}$ \\
\hline 2. & $\begin{array}{l}\text { Kebun Purwosari } \\
\text { B } \\
\text { Kel. Purwosari. } \\
\text { Kec. Mijen } \\
\text { 2,5 Ha }\end{array}$ & $\begin{array}{l}138 \text { Jambu air, } 88 \\
\text { Durian, } 10 \text { Sukun, } 90 \\
\text { Jambu kristal dan } 2 \text { Petai }\end{array}$ \\
\hline 3. & $\begin{array}{l}\text { Kebun Purwosari } \\
\text { C } \\
\text { Kel. Purwosari. } \\
\text { Kec. Mijen } 0,8 \mathrm{Ha} \\
\end{array}$ & $\begin{array}{llr}112 \text { Kelengkeng, } & 100 \\
\text { Jambu kristal, dan } & 72 \\
\text { Jeruk } & & \end{array}$ \\
\hline 4. & $\begin{array}{l}\text { Kebun Bubakan } \\
\text { Kel. Bubakan . } \\
\text { Kec. Mijen } 2 \mathrm{Ha}\end{array}$ & $\begin{array}{lr}150 \quad \text { Kelengkeng, } & 267 \\
\text { Jambu kristalin, } & 50 \\
\text { Durian. } 34 \text { Sirkaya, dan } \\
\text { 72 Srikaya Grand anona }\end{array}$ \\
\hline 5. & $\begin{array}{l}\text { Wates } \\
\text { Kel. Wates 5,5Ha } \\
\text { Kec. Ngaliyan } \\
5,5 \mathrm{Ha}\end{array}$ & $\begin{array}{lr}355 \quad \text { Kelengkeng, } & 157 \\
\text { Jambu kristal , } 69 \\
\text { Srikaya, } 300 \quad \text { Jambu } \\
\text { kristal, } 300 \text { Sirsat madu } \\
\text { dan } 85 \text { Kelengkeng } \\
\end{array}$ \\
\hline 6. & $\begin{array}{l}\text { Gunungpati } \\
\text { Kel. Gunungpati } \\
\text { Kec. Gunungpati } \\
1,2 \mathrm{Ha}\end{array}$ & $\begin{array}{l}32 \text { Durian, } 114 \\
\text { Kelengkeng, 42 Jambu } \\
\text { kristal, } 47 \text { Sirsat madu, } \\
210 \text { Jambu kristal, } 28 \\
\text { Grand anona }\end{array}$ \\
\hline 7. & $\begin{array}{l}\text { Plalangan. Kel. } \\
\text { Plalangan. } \\
\text { Kec. Gunungpati } \\
10 \mathrm{Ha} \\
\end{array}$ & Belum ditanami \\
\hline 8. & $\begin{array}{l}\text { Cepoko } \\
\text { Kel. Cepoko } \\
\text { Kec. Gunungpati } \\
\text { 3,2 Ha }\end{array}$ & $\begin{array}{ll}359 \text { Kelengkeng, } & 390 \\
\text { Jambu kristal, } & \\
300 \text { Sirsat madu, } & 65 \\
\text { Kelengkeng, dan } & 19 \\
\text { Durian } & \\
\end{array}$ \\
\hline 9 & $\begin{array}{l}\text { Nongkosawit. } \\
\text { Kel. } \\
\text { Nongkosawit. } \\
\text { Kec. Gunungpati }\end{array}$ & $\begin{array}{ll}119 \text { Kelengkeng, } & 100 \\
\text { Jambu kristal, } \\
25 \text { Grand anona, } & 100 \\
\text { Sirsat madu }\end{array}$ \\
\hline
\end{tabular}

Ekonomi, Sosial, dan Budaya 1416 


\begin{tabular}{|c|c|c|}
\hline & $3,2 \mathrm{Ha}$ & \\
\hline 10 & $\begin{array}{l}\text { Kramas } \\
\text { Kel. Pedalangan } \\
\text { Kec. } \\
\text { Banyumanik 2Ha }\end{array}$ & $\begin{array}{l}150 \text { Kelengkeng, J57 } \\
\text { jambu kristal, } \\
7 \text { Srikaya, } 10 \text { Durian, } 34 \\
\text { Rambutan. } 200 \text { Jambu } \\
\text { kristal, } 60 \text { Sirsat madu, } \\
\text { dan 30 kelengkeng }\end{array}$ \\
\hline 11. & $\begin{array}{l}\text { Tambangan } \\
\text { Kel. Tambangan. } \\
\text { Kec. Mijen } \\
\text { 2,3 Ha }\end{array}$ & $\begin{array}{l}12 \text { Anggrek dendrobium. } \\
31 \text { Anggrek bulan, } 40 \\
\text { Anggrek dendrobium, } \\
26 \text { Anggrek bulan, } 1862 \\
\text { Anggrek dendrobium } \\
943 \text { Anggrek } \\
\text { dendrobium, } \\
575 \text { Anggrek remaja, } 25 \\
\text { Jambu citra }\end{array}$ \\
\hline 12. & $\begin{array}{l}\text { Cangkiran. Kel. } \\
\text { Cangkiran } \\
\text { Kec. Mijen 1,2 } \\
\text { Ha }\end{array}$ & Padi \\
\hline
\end{tabular}

Sumber : Dinas Pertanian (2018)

Khusus untuk Kawasan kebun buah di Kecamatan Mijen, tepatnya di Kelurahan Purwosari. Dinas Pertanian sedang merintis Agrotechno-Edupark. Inisiasi ini sudah dimulai sejak tahun 2014, berangkat dari latar belakang kebutuhan kawasan agribisnis yang terintegrasi hulu dan hilir. Kawasan Agrotechno-Edupark Purwosari memiliki luas 17,89 ha yang dikelola bersama-sama dengan anggota kelompok tani KT Mbangun Karso (anggota 50 orang), KT Loh Jinawi (66 orang), dan KT Subur Makmur (30 orang). Jenis tanaman buahbuahan yang dibudidayakan oleh petani berasal dari jenis lokal dan jenis unggul.

Capaian pembangunan fisik yang sudah dilaksanakan adalah pembangunan area parkir, lavatory, pedestrian, green house hidroponik, green house buah dan sayuran, serta joglo pertemuan. Agrotechno-Edupark Purwosari nantinya memiliki 2 (dua) fungsi, yaitu pertama untuk pengembangan inovasi pertanian dan kedua sebagai tempat pelatihan pemagangan, pusat disseminasi teknologi dan pusat advokasi bisnis ke masyarakat luas. Sementara itu, tujuan pembuatan ATP Purwosari adalah (1) sarana pengembangan teknologi pertanian, (2) sarana promosi pertanian, (3) pengembagan agro-eduwisata, dan terakhir (4) meningkatkan PAD sector pertanian.
Beberapa permasalahan yang muncul : pertama, rendahnya kualitas dan kuantitas sumber daya pertaniandi tingkat petani; kedua, terbatasnya anggaran, serta belum optimalnya pemanfaatan sarana dan prasarana kebun Dinas Pertanian; ketiga, belum terintegrasinya program pemerintah daerah didalam pengelolaan asset dan belum tersedianya instrument pengaturan sehingga keberadaan kebun kurang memberikan manfaat bagi petani maupun masyarakat sekitarnya.

Berdasarkan permasalahan yang ada, maka solusi yang diberikan adalah membuat rintisan Agrotechno-Edupark beserta instrument pengaturannya melalui Program Kemitraan Wilayah. Keberadaan Agrotechno-Edupark Purwosari ke depan diharapkan selain menjadi pusat pengembangan inovasi pertanian juga dikembangkan ke arah agro-eduwisata seiring dengan program "Merdeka Belajar" dari Kemendikbud. Kondisi ini juga didukung oleh meningkatnya jumlah wisatawan ke Kota Semarang dan tren wisata Pendidikan Alam. Untuk mencapai tujuan tersebut dilakukan berbagai kegiatan yang bersifat aplikatif dan berkesinambungan dengan model kemitraan (business partnership). Model kemitraan melibatkan multistakeholder meliputi unsur Akademisi (Universitas Negeri Semarang dan UPGRIS), Pebisnis (BATAN \& Yayasan Obor Tani), Komunitas Petani dan Dinas Pertanian Kota Semarang sehingga tercipta sebuah jejaring kemitraan quadruple helix yang akan meningkatkan keberhasilan program [Soesilowati, et al, 2017].

Techno park pertama kali dirintis oleh Amerika Serikat pada awal 1950-an, yang diawali dengan mendirikan research park di Universitas Standford, California. Sebuah universitas swasta yang memiliki kesulitan finansial untuk menarik minat dosen dan menggaji karyawan, tetapi memiliki lahan kampus yang kosong dan luas namun tidak diperkenankan oleh pemiliknya untuk menjualnya, sehingga melalui inisiasi Frederick Terman (salah satu guru besar Universitas Stanford) dimanfaatkan semaksimal mungkin dengan mendirikan research park, yang menyewakan lahan kepada perusahaan-perusahan berteknologi tinggi dan menyediakan modal ventura bagi perusahaanperusahaan pemula, serta menempatkan sumber daya ilmiah departemen berteknologi tinggi di wilayah research park.

Ekonomi, Sosial, dan Budaya 
Meskipun pembangunan infrastruktur dan pembebasan tanah untuk research park tersebut membutuhkan waktu tiga puluh tahun namun hasilnya, research park yang mendorong tumbuhnya Silicon Valley yang terkenal ini, memiliki prestasi yang fenomenal dalam pengembangan industri berbasis ilmu pengetahuan, termasuk menciptakan perusahaan-perusahaan terkenal di dunia saat ini seperti Hewlett Packard (HP), Adobe Systems, Apple Computer, Google, Intel, Yahoo, dan eBay. Perusahaan yang tumbuh di daerah sekitar Universitas Standford inilah yang mendorong kesuksesan Silicon Valley, sehingga membuat beberapa negara di dunia mempelajari cara-cara yang ditempuh oleh Standford University [Wawan.T, 2018)].

Pembangunan Technopark di Indonesia telah diimplementasi di Bandung dengan berdirinya Bandung Techno Park (BTP) sebagai pusat Teknologi Informasi dan Komunikasi (TIK), yang hingga saat ini dijadikan role model bagi pembangunan 100 Science and Techno Park (STP) di Indonesia. Berbagai produk hasil riset yang telah dikomersialisasikan oleh BTP antara lain : (1) UKit, sebuah perangkat kit mikrokontroler yang dengannya pengguna dapat mempelajari berbagai fitur yang terdapat pada sebuah mikrokontroler dengan pilihan input dan output yang beragam; (2) STUDIA, konsep e-Learning ataupun distance learning; (3) IDMAX, sistem presensi yang menggunakan prinsip gelombang radio, yang manisfestasinya dapat berupa ID card, gelang, pin, dan lainnya; (4) SMART Parking System; (5) AGV (Automated Guide Vechile), berupa robot pengangkut otomatis; (6) LoRaID (Long Range Identification System); (7) Incinerator Solair, merupakan solusi pembakaran sampah; serta (8) PMB (Production Monitoring Board), yang berfungsi untuk memantau kinerja dalam suatu produksi dan memberi informasi ada sistem kerja sebuah pabrik.

Berbeda dengan Bandung Techno Park (BTP), juga terdapat Solo TechnoPark (STP) yang merupakan kawasan terpadu berbasis ilmu pengetahuan dan teknologi. Saat ini STP menjelma menjadi sebuah lembaga pendidikan dan pelatihan (DIKLAT) di bidang mekanik bertandar internasional yang berhasil memberikan kontribusi dalam memberikan diklat kepada generasi muda yang belum bekerja. Hal tersebut disebabkan oleh selain sebagai pusat vokasi, STP yang dibangun dengan model Triple Helix juga dimanfaatkan sebagai pusat riset teknologi terapan.

Ganesha Sukowati Techno Park (GSTP) yang biasa disebut dengan Sragen Technopark juga bergerak pada sektor otomotif, elektronik, dan ICT. GSTP dibangun di atas areal milik pemerintah daerah Sragen pada tahun 2009. GSTP didirikan dengan tujuan menetapkan dan mengimplementasikan R\&D, pelatihan, kemandirian, maupun kerjasama untuk meningkatkan keahlian, tenaga kerja, produk, dan pelayanan yang mempunyai nilai jual dan nilai tambah bagi pemerintah dan masyarakat Sragen. Dengan luas hampir 30 ha, selain diarahkan ke industri/teknik, nantinya juga ada ke arah penyiapan SDM di bidang agro-industri dengan menjalankan fungsi One Stop Labor Market (OSSLM)

Jababeka Research Center (JRC) merupakan sebuah Bussiness Technonology Center di kawasan industri Jababeka yang mempunyai visi sebagai sebuah lembaga intermediasi yang kompeten. $J R C$ menghubungkan antara pemasok teknologi (lembaga litbang dan perguruan tinggi) dengan pengguna teknologi (khususnya industri yang berada di kawasan) dengan harapan untuk memiliki kontrak kerjasama. Adapun industri yang telah mengembangkan bisnisnya di $J R C$ adalah Samsung Electronic, ICI, Mattel, KAO, dan Niisin. JRC juga mengalokasikan lahan yang dikembangkan untuk keperluan yang spesifik seperti Movieland yang dikhususkan untuk industri film dan televisi, Medical City untuk kawasan khusus healthcare, dan Education Park yang menjadi lokasi President University

Di wilayah Cibinong, kabupaten Bogor, terdapat Cibinong Science Center (CSC) yang dikelola oleh Lembaga Ilmu Pengetahuan Indonesia (LIPI), dengan luas sekitar 189,6 Ha. Kawasan CSC seperti direncanakan sejak awal akan menjadi pusat kegiatan penelitian, pengembangan, inovasi, serta sistem manajemen informasi sains bidang ilmu hayati. CSC merupakan kawasan bernuansa teknologi yang ditujukan untuk pewadahan kegiatan pengembangan teknologi dan industri berbasis teknologi yang berada di Kota Cibinong. 
Pembagian zona kawasan pada wilayah CSC yaitu perkantoran, penghijauan, dan kemitraaan dengan pihak luar. Kini CSC yang dikembangkan menjadi acuan perkembangan penelitian hayati di Indonesia, memiliki potensi dalam pengembangan bio-hydro untuk kepentingan industri, kebun plasma nutfah tumbuhan dan hewan, Ecology Park (Eco Park) dengan luas sekitar 21 ha.

Pusat Penelitian Ilmu Pengetahuan dan Teknologi adalah kawasan riset terbesar di Indonesia yang biasa dikenal dengan kawasan Puspiptek Serpong. Tujuan pembangunan Puspiptek pada saat itu adalah untuk memindahkan sejumlah pusat milik Lembaga Ilmu Pengetahuan Indonesia (LIPI), Badan Tenaga Nuklir Nasional (BATAN), dan Badan Pengkajian dan Penerapan Teknologi (BPPT) ke suatu kawasan. Beberapa laboratorium dibangun untuk menunjang BUMN industri strategis seperti PT. IPTN (sekarang PT. DI) dan PT PAL. Dengan tujuan untuk mendukung proses industrialisasi di Indonesia maka Puspiptek dirancang untuk menjadi kawasan yang mensinergikan SDM terdidik dan terlatih, peralatan penelitian dan pelayanan teknis yang paling lengkap di Indonesia serta teknologi dan keahlian yang telah terakumulasikan selama lebih dari seperempat abad.

Khusus bidang pertanian, peternakan dan perikanan, kawasan Agro Techno Park (ATP) dibangun untuk memfasilitasi percepatan alih teknologi pertanian yang dihasilkan oleh instansi pemerintah penelitian dan pengembangan, pendidikan tinggi dan perusahaan yang juga sebagai model pertanian terpadu oleh siklus biologis (bio cyclo farming). Lokasi ATP antara lain Kabupaten Ogan Ilir dan Muara Enim (2003, Sumsel), Kabupaten Kaur, Bengkulu, Cianjur (2007, Koleberes Cikadu, Cianjur), dan Jembrana (2007, Bali). Pada awal pendiriannya, ATP dikelola oleh Kementerian Negara Riset dan Teknologi yang bermitra dengan Pemerintah Daerah, Perguruan Tinggi Lokal / Sekolah Kejuruan. Baru tahun 2011, ATP secara bertahap diserahkelolakan ke pihak pemerintah daerah atau perguruan tinggi setempat seperti pada tanggal 20 April 2011 dilaksanakan pendatanganan naskah alih kelola dan serah terima sementara ATP Jembrana dari kementerian riset dan teknologi kepada Pemda Kabupaten Jembrana. Adapun program dan kegiatan ATP antara lain di bidang pertanian, perikanan, peternakan, dan teknologi transfer.

Pertanian selama ini hanya dihargai karena kemampuannya dalam menghasilkan bahan pangan, sedangkan fungsi lain pertanian di bidang lingkungan, sosial, budaya, dan ekonomi belum banyak dimanfaatkan atau cenderung masih diabaikan. Konsep multifungsi pertanian memiliki peran penting dalam mereposisikan kedudukan sektor pertanian dalam fungsi yang semestinya. Dengan penerapan konsep multifungsi pertanian dengan menerapkan kemajuan teknologi yang ada serta serta penataan ruang yang sesuai dengan nilai edukasi, daya guna, dan estetika dapat memaksimalkan nilai fungsi pertanian yang memiliki peran penting dalam menunjang kehidupan.

Agrotehno- edupark merupakan suatu gagasan yang tepat dalam menerapkan konsep multifungsi pertanian. Secara tata bahasa agrotechno edupark yang berasal dari kata agro yang berarti pertanian, techno berarti teknologi, edu berarti edukasi atau proses belajar, dan park yang berarti taman wisata atau rekreasi. Sehingga agrotechno edupark dapat diartikan sebagai penerapan suatu konsep sistem pertanian presisi yang diintegrasikan dengan penerapan teknologi tepat guna yang dirancang dan dikonsepkan sebagai taman wisata edukasi.

Agrotechno edupark merupakan bagian dari objek wisata yang memanfaatkan usaha pertanian (agro) sebagai objek wisata. Tujuannya adalah untuk memperluas pengetahuan, pengalaman rekreasi, dan hubungan usaha dibidang pertanian. Melalui pengembangan agrotechno edupark yang menonjolkan budaya lokal dalam memanfaatkan lahan, diharapkan bisa meningkatkan pendapatan petani sambil melestarikan sumber daya lahan, serta memelihara budaya maupun teknologi lokal (indigenous knowledge) yang umumnya telah sesuai dengan kondisi lingkungan alaminya. Agrotechno edupark juga merupakan sarana edukasi terhadap masyarakat luas tentang budidaya pertanian dan pentingnya dalam memperhatikan keseimbangan serta kelestarian ekosistem.

Agrotechno-edupark harus memperhatikan beberapa prinsip dalam pengembangan dan pengelolaannya. Prinsif-prinsif tersebut, menurut

Ekonomi, Sosial, dan Budaya 1419 
Wood, 2000 adalah sebagai berikut : (1) Menekankan serendah-rendahnya dampak negatif terhadap alam dan kebudayaan yang dapat merusak daerah tujuan wisata; (2) Memberikan pembelajaran kepada wisatawan mengenai pentingnya suatu pelestarian; (3) Menekankan pentingnya bisnis yang bertanggung jawab, dimana terdapat kerjasama antar unsur pemerintah dan masyarakat serta memberikan manfaat pada usaha pelestarian; (4) Mengarahkan keuntungan ekonomi secara langsung untuk tujuan pelestarian, menejemen sumberdaya alam dan kawasan yang dilindungi; (5) Memberi penekanan pada kebutuhan zone pariwisata regional dan penataan serta pengelolaan tanam-tanaman ; (6) Memberikan penekanan pada kegunaan studi-studi berbasiskan lingkungan dan sosial, serta program jangka panjang.; (7) Mendorong usaha peningkatan manfaat ekonomi untuk negara, pebisnis, dan masyarakat lokal, terutama penduduk yang tinggal di wilayah sekitar kawasan yang dilindungi; (8) Berusaha untuk meyakinkan bahwa perkembangan pariwisata tidak melampui batas-batas sosial dan lingkungan yang dapat diterima seperti yang ditetapkan para peneliti yang telah bekerjasama dengan penduduk local; (9) Mempercayakan pemanfaatan sumber energi, melindungi tumbuhtumbuhan dan binatang liar, dan menyesuaikannya dengan lingkungan alam dan budaya .

Dewasa ini, kehidupan masyarakat dipenuhi dengan kejenuhan, rutinitas dan segudang kesibukan sehingga membutuhkan sarana refreshing, Pengembangan agrotechno edupark Purwosari diarahkan dalam bentuk ruangan tertutup (Grenn house), ruangan terbuka (taman atau lansekap), dan kombinasi antara keduanya. Komponen utama pengembangan agrotechno edupark ruangan terbuka berupa flora dan fauna yang dibudidayakan maupun liar, teknologi budi daya dan pascapanen komoditas pertanian yang khas, atraksi budaya pertanian setempat, dan pemandangan alam berlatar belakang pertanian dengan kenyamanan yang dapat dirasakan

\section{METODE}


dan manajemen usaha; dan (9) Pelatihan pembuatan souvenir

Kedua, Membangun business partnership hulu hilir industry kecil olahan makanan dan ekonomi kreatif dengan kegiatan meliputi : (1) Fasilitasi promosi produk melalui pameran; (2) Pembuatan leaflet dan Banner usaha untuk promosi. Ketiga, Inkubasi Bisnis dengan kegiatan : (1) Perekrutan tenant; (2) Fasilitasi uji kelayakan business; dan (3) Pelatihan pembuatan business plan

\section{HASIL DAN PEMBAHASAN}

Program kemitraan wilayah rintisan Agrotechno-edupark merupakan bentuk kolaborasi Dinas Pertanian Kota Semarang, Akademisi UNNES, UPGRIS, BATAN serta Yayasan Obor Tani dengan dukungan pendanaan dari APBD dan Kementrian Ristek-BRIN selama tiga tahun. Kegiatan meliputi : pertama, Pelatihan dan pendampingan tehnik pembibitan, budidaya, pemupukan tanaman durian, kelengkeng, jambu biji, marqisa, dan melon. Pelatihan pembibitan dan budidaya tanaman melibatkan Yayasan Obor Tani beserta dosen ahli biologi UNNES. Aspek penting yang dikaji dalam penerapan agroforestri diantaranya aspek teknis agronomis, silvikultur, aspek sosial ekonomi serta aspek ekologi. Aspek teknis agronomis dan silvikultur yaitu kajian kesesuaian kombinasi antara tanaman kehutanan dan tanaman pertanian untuk mendapatkan produktivitas yang lebih tinggi. Kajian aspek sosial ekonomi diantaranya mempelajari kombinasi jenis tanaman bagaimana yang dapat memberikan pendapatan yang menguntungkan bagi petani [Suharjito. et al, 2003].
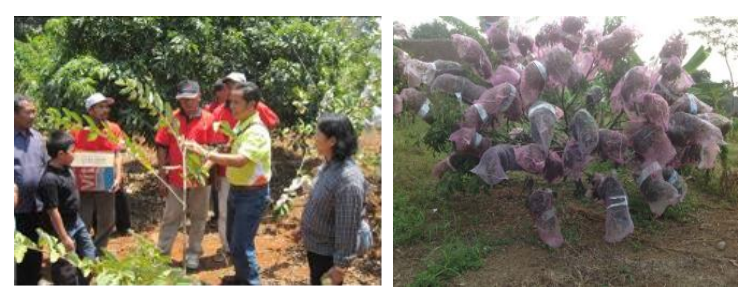
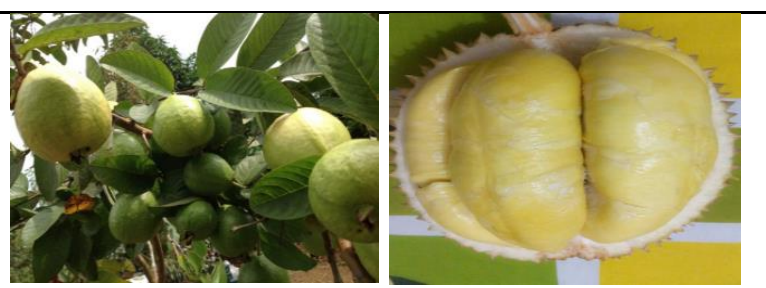

Gambar 1. Pelatihan/Pendampingan Teknologi

Budidaya

Kedua, Pengolahan pasca panen. Untuk mengolahan hasil panen dibentuklah KUB "Sekar Tani” yang beranggotakan Kelompok Wanita Tani. Pembentukan KUB "Sekar Tani” diharapkan : (1) meningkatkan keterampilan Kelompok Wanita Tani dalam pengelolaan hasil produksi pertanian ; (2). meningkatkan pendapatan keluarga; (3) penyediaan kuliner dalam rangka mendukung keberadaan agrotechno-edupark; (4) mempererat hubungan sosial ekonomi dalam masyarakat dan pihak lainnya [Ahmadi.A. et al, 2016]. Produk dikemas, diberi merk serta dilegalitaskan melalui ijin edar. Sebagai fasilitator kegiatan adalah dosen jurusan tata boga dengan pendampingan mahasiswa KKN. Beberapa produk yang sudah keluar IUMK adalah : minuman marqisa, Coctail buah, kripik, beras organic, obatobatan \& pupuk, serta souvenir kaos
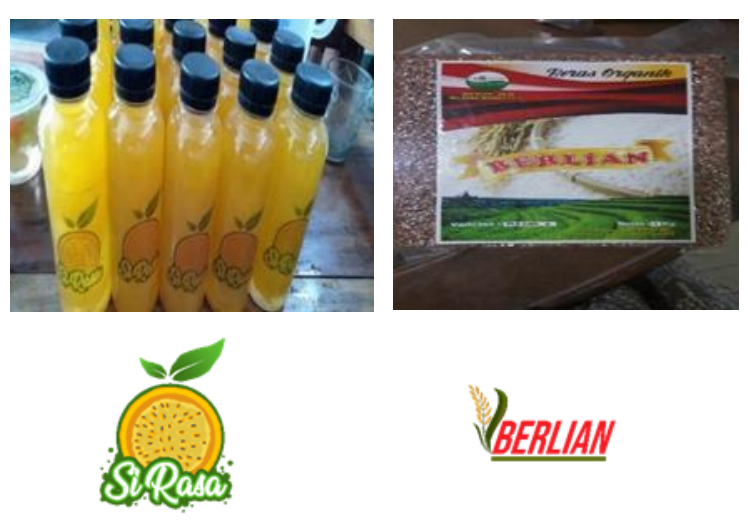

Gambar 2. Produk dan merk dagang KUB "Sekar Tani"

Ketiga, Penguatan Kelompok Sadar Wisata (Pokdarwis) dan mengintegrasikan program diberikan pelatihan dan pendampingan terkait eduwisata dengan materi : penyadartahuan, story telling, panduan guiding, bagaimana mewujudkan 
Agrotechno- edupark yang dapat memenuhi kriteria Sapta Pesona wisata Indonesia. Dalam kegiatan ini anggota pokdarwis juga berlatih cara menerima tamu, memberikan ice breaking, memberikan story telling dan mendampingi anak-anak sekolah berkeliling kebun buah agro purwosari. Kegiatan Agrotechno-park dikemas dalam beberapa paket, Paket A : panen sayur hidroponik. Paket B : tour kebun hidroponik, simulasi hidroponik, dan panen sayur. Paket C : tour kebun buah, tour kebun hidroponik dan simulasinya, panen sayur serta mendapatkan buah dan minuman olahan. Paket D : tour ke sawah dan menanam padi, tour ke kendang dan memberi makan ternak, dengan souvenir susu dan beras organic.
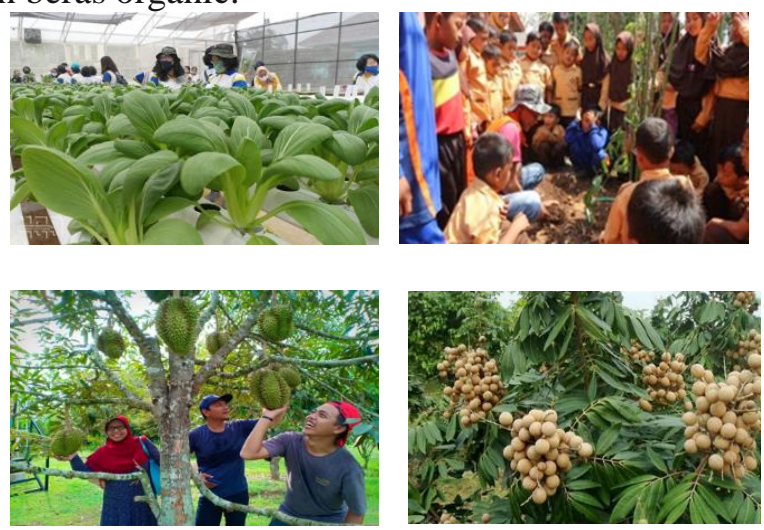

Gambar 3. Kegiatan Eduwisata

Melalui pengembangan agrotechno edupark yang menonjolkan budaya lokal dalam memanfaatkan lahan, diharapkan bisa meningkatkan pendapatan petani sambil melestarikan sumber daya lahan, teknologi lokal (indigenous knowledge). Agrotechno edupark juga merupakan sarana edukasi terhadap masyarakat tentang budidaya pertanian dan pentingnya dalam memperhatikan keseimbangan serta kelestarian ekosistem [M F Alim, 2020]

Keempat, Pembangunan Sarana/ Prasarana Untuk meningkatkan pemasaran produk mitra diselenggarakannya kegiatan Pameran Semarang Agro Expo yang diselenggarakan oleh Dinas Pertanian Kota Semarang beserta mitra binaan. Untuk merevitalisasi fungsi kebun maka dilengkapi sarana prasarana seperti Green House, joglo, pasar tani, out bond dan spot selfi. Kelompok masyarakat, dalam hal ini KUB Sekar Tani dan Kelompok Tani
Sumber Rejeki akan menjadi kelompok pengelola yang merawat dan mengurus kegiatan Pasar Tani. Adapun tujuan pembangunan pasar tani adalah : (1) Meningkatkan pendapatan masyarakat melalui guna mendukung fungsi kebun Purwosari sebagai tempat Agrotechno-edupark; (2) Berkontribusi mengembangkan sumber alternatif perolehan PAD.
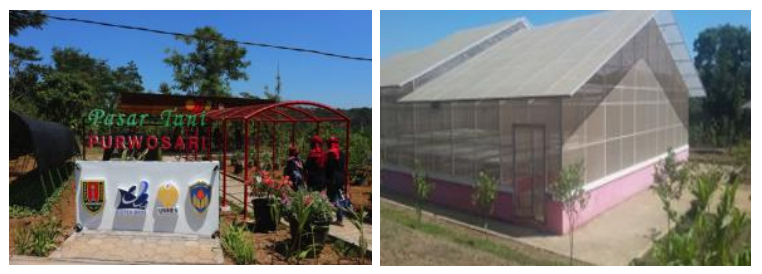

Gambar 4. Sarana/ prasarana Pasar Tani $\&$ Green House

KUB sebagai pendukung keberadaan Agrotechno-Edupark memperluas usaha yang berkaitan dengan kegiatan anggota maupun non anggota meliputi : Jasa Catering, Souvenir, Pemandu Wisata, Kesenian, Jasa Penyewaan Perlengkapan Pesta, Penjualan Bibit Holtikultura, Penjualan Saprotan (sarana prodi pertanian), serta Paket Tour dan Eduwisata.

Pertama, Membangun kemitraan (business partnership). Kemitraan dilakukan dengan multistakeholder. Masing-masing aktor berkontribusi sesuai fungsi kelembagaannya dimasyarakat. Unnes \& UPGRIS (A), Batan \& Yayasan Obor Tani (B), Pemerintah Kota Semarang (G) termasuk dalam Triple Helix. Masyarakat Tani dan Masyarakat berbasis Media dan Budaya (C) masuk dalam Quadruple Helix. Menurut ekonomi Austria, perkembangan ekonomi harus dilihat sebagai proses perubahan kualitatif yang didorong oleh inovasi yaitu kombinasi dari sumber daya yang ada [Fagerberg, J, 2003]. Akademisi dengan dukungan mahasiswa KKN dan perusahaan menyediakan kondisi yang diperlukan untuk ekosistem inovasi terpadu melalui teknologi tepat guna. Pemerintah Kota Semarang sebagai penguasa wilayah menyediakan sarana danprasaran lahan. Masyarakat tani, media serta penggiata wisata tidak hanya menggunakan dan menerapkan pengetahuan, dan menuntut inovasi dalam bentuk barang dan jasa, namun juga menjadi bagian aktif 
dari sistem inovasi. Teknologi informasi dan komunikasi (TIK) bekerja sebagai faktor pendukung partisipasi bottom-up masyarakat sipil.
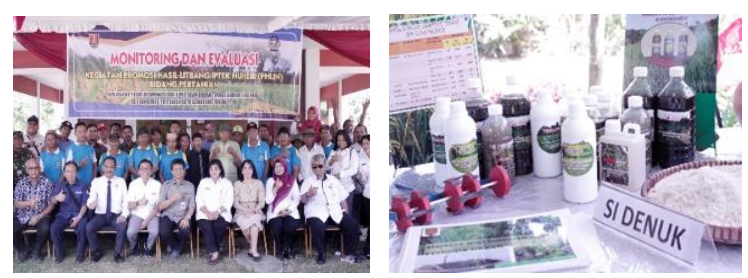

Gambar 5. Kegiatan Promosi Hasil Litbang UNNES, UPGRIS, BATAN, PEMKOT

Semarang dan Petani

Quadruple Helix mengkontekstualisasikan Triple Helix dengan menambahkan sebagai masyarakat sipil helix " dan publik berbasis media dan budaya. Pemahaman bahwa perspektif tambahan harus ditambahkan untuk memahami inovasi dalam abad ke-21 yang sedang berlangsung. Triple Helix tidak benar-benar cukup sensitif untuk menceminkan kondisi demokratik, sedangkan Quadruple Helix merefleksikan hal tersebut [Woo Park H, 2014].

Kedua, Membentuk instrument kebijakan pengaturan melalui penyusunan Naskah Akademik dan Raperda Retribusi Bidang Pertanian. Perda retribusi bidang pertanian diperlukan sebagai legalitas usaha bidang pertanian, khususnya terkait retribusi pemanfaatan asset negara, penjualan produk usaha di era reinventing government. Carayannis dan Campbell (2009) menyatakan pentingnya kebijakan dan praktik pemerintah, universitas dan industri serta masyarakat sipil saling berinteraksi secara cerdas, efektif dan efisien. Secara paralel, konsep Quadruple Helix dikembangkan dengan mempertahankan interaksi dari lingkungan akademisi, dunia industri, dan pemerintah serta dengan meresmikan peran masyarakat sipil [Yawson, R. M, 2009]

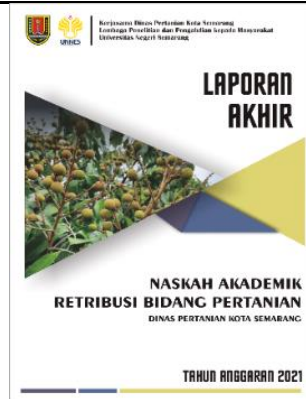

Gambar 6. Naskah Akademik Perda Retribusi Bidang Pertanian

\section{KESIMPULAN}

Keberhasilan Agro Tekno-Park pada tataran operasional, tergantung pada rancang bangun inovasi pertanian yang meliputi aspek teknis dan kelembagaan. Kelembagaan berada di level makro (lingkup Kementan dan jajarannya), messo (pemerintah daerah) dan level mikro (kelompok tani). Dari berbagai program kegiatan yang dilakukan secara terintegrasi dan berkesinambungan telah memunculkan 3 kelompok wirausahawan baru yang saling mendukung, meliputi bisnis buahbuahan, kuliner, dan jasa wisata yang berimbas pada meningkatkan pendapatan. Program kemitraan wilayah dalam pembentukan Argo Tekno Park menjadi efektif karena meningkatkan produktivitas buah-buahan lokal lebih dari $100 \%$ serta melibatkan multistakeholder.

Sisi positif dari rintisan agrotechno edupark adalah : (1) melestarikan sumber daya alam, (2) mengkonversi teknologi local, (3) meningkatkan pendapatan petani, masyarakat sekitar dan PAD, dan (4) sebagai sarana edukasi

Lalu, apa yang perlu dilakukan untuk pemerintah untuk mendukung keberhasilan Agrotechno-edipark? Pertama, perlu melakukan pengawalan dan pendampingan teknologi yang lebih intensif agar pelaku utama dapat menerapkan teknologi sesuai rekomendasi. Ke dua, menyediakan fasilitas yang atraktif bagi pendamping agar dapat bekerja optimal. Ke tiga, melakukan monitoring dan evaluasi berjenjang dan periodik sehingga jika ada sesuatu yang kurang dapat segera terdeteksi untuk diperbaiki. Dengan rancang bangun inovasi yang efektip, dan dukungan Pemda yang kondusif, serta diikuti pengawalan 
teknologi oleh peneliti/pendampingan oleh akademisi, penyuluh yang lebih intensif, pembangunan Agrotechno-edupark akan mendorong terjadinya penderasan inovasi teknologi pertanian. Pada gilirannya akan memacu produksi pertanian dan memberikan kontribusi pencapaian swasembada pangan.

\section{UCAPAN TERIMAKASIH}

Puji syukur kami panjatkan atas kehadirot Allah SWT atas ridhonya dan juga terimakasih yang terhingga kami sampaikan kepada Ristek-BRIN dan Dinas Pertanian Kota Semarang yang telah memberikan dukungan pendanaan,sehingga kegiatan pengabdian ini dapat terlaksana dengan lancar tanpa hambatan yang berarti. Semoga Rintisan Agritechno-Edupark bermanfaat bagi masyarakat, khususnya warga Kelurahan Purwosari.

\section{REFERENSI}

Akmadi A, Rita NS. (2016). Pemanfaatan Teknologi Pascapanen Untuk Pengembangan Agroindustri Perdesaan Di Indonesia. Forum Penelitian Agro Ekonomi, Vol. 34 No. 1, Juli: 21-34

BAPPENAS. (2019). Pedoman Perencanaan Science Park dan Techno Park Tahun 20152019. Jakarta.

BPS. (2018). Kota Semarang Dalam Angka 2018. Semarang: Badan Pusat Statistik Kota Semarang.

Dinas Pertanian Kota Semarang. (2018). Perubahan Kedua Rencana Strategis (P-RENSTRA) Dinas Pertanian Kota Semarang Tahun 2016 $-2021$

Fagerberg, J. (2003). Schumpeter and the revival of evolutionary economics : an appraisal of the literature. Journal of Evolutionary Economics, 13(2), 125-159.

Yawson, R. M. (2009), The Ecological System of
Innovation: A New Architectural Framework for a Functional Evidence-Based Platform for Science and Innovation Policy, The Future of Innovation, Proceedings of the XXIV ISPIM 2009 Conference, Vienna, Austria, June 2124 ,

M F Alim, A P Nugroho, S. S Arif . Murtiningrum and L. Sutiarso. (2020). Development of knowledge management system for assisting the Agrotechno Edu-park establishments in Sriharjo village, Imogiri district, Bantul regency. IOP Conf. Series: Earth and Environmental Science 542

Soesilowati, E., Kariada, N., \& Margunani. (2017). Model for Empowering Farmers at Dry Land through Quadruple Helix Approach. Journal of Arts \& Humanities, 6(4), 1-9

Soenarso, W.S. Pengembangan Science and Techno Park di Indoensia. (2018) Http:// www.opi.lipi.go.id/data/1228964432/data/13 $\underline{086710321320826500 .}$.

Suharjito, D., Sundawati, L., dan Utami, S.R. (2003). Aspek Sosial Ekonomi dan Budaya Agroforestri (Bahan Ajaran Agroforestri 5). Book. World Agroforestry Centre, Bogor.

Woo Park H. (2014), Transition from the Triple Helix to N-Tuple Helices? An interview with Elias G. Carayannis and David F. J. Campbell, Scientometrics 99:203-207, DOI 10.1007/s11192-013-1124-3. 